\title{
The Hoover Library on War, Revolution, and Peace
}

The reference librarian of the Hoover Library describes that library as an example of the constructive use of the printed page.

$\mathrm{T}^{\mathrm{N}}$ 1914, Herbert Hoover sensed the sig1 nificance of the World War which was then beginning. He visualized its far reaching effects and resolved that the records of the crisis should be preserved and gathered together at Stanford University. Mr. Hoover's widespread European activities in the administration of relief both during and after the war provided unique opportunities for the development of such a project. Even during the period of hostilities he was able to assemble a large amount of war data. However, the main task of collecting was inaugurated at the close of the war, and it is being continued at the present time.

As its name implies, the library has a threefold purpose: (I) its aim is to present an accurate historical picture of the causes, events, and results of the World War of 1914-I8; (2) it attempts to show how this conflict brought about chaotic conditions resulting in the present upheaval of the world today; (3) it makes available a study of the varied efforts which have been used or are being used to remedy such conditions.

The materials concerning the underlying causes of the World War deal with the diplomatic alignments of the great powers since $187 \mathrm{I}$, the question of economic imperialism, and the problems of nationalism. The records for the war period cover all political, economic, and social phases of the world conflict. For the period immediately following the war, research data have been gathered on the various treaties of peace, on the revolutionary movements resulting from the war, and on the various relief measures put into effect in post-war Europe.

The library has been made as adequate as possible on the period of transition from war conditions to normal postwar conditions during the years 1919-25. The subjects for this general period of reconstruction include the political and economic reorganization of the belligerent and neutral states, the political and social movements arising from the war, and the enforcement of the treaties of peace through the various organizations set up to carry out its provisions.

Many phases of the late postwar period and problems of the present day can also be studied. The Hoover Library has gathered most valuable materials on the questions of inter-Allied debts, reparations, rehabilitation of currencies, and general fiscal conditions. The history and development of such international organizations as the League of Nations, the World Court, the International Labour Office, and the Institute of Pacific Relations can be investigated. The library offers un- 
rivaled resources for research on the present situation in central and eastern Europe, through its unique collections which deal with the development of Communism in Russia, the rise of Fascism in Italy and the growth of National Socialism in Germany.

\section{Chiefly for Use of Historians}

The library has concentrated, however, upon the preservation of records for the use of the historian, and has given little notice to the acquisition of material commonly found in museums. It contains approximately 25,000 volumes of government documents from 60 countries or states, 8o,00o books and pamphlets, 31,000 posters and photographs, over 2 IOO sheets of official maps, and $28 \mathrm{I}$,000 feet of 35 $\mathrm{mm}$. film. The newspaper collection of the Hoover Library contains over I 700 titles in 26 languages and covers the press of 40 countries. Many of the papers are to be found nowhere else in the United States. The collection of periodicals numbers over 7000 titles in 32 languages from 44 countries.

In this paper I shall confine myself to that section of the library dealing with the actual World War, and describe the various types of material which facilitate the study of this great crisis.

I shall discuss first the military data. Prominent in this section are the official military and naval histories published by the various governments in order to narrate and commemorate their own military and naval activity. The German government is at the present time publishing its official history under the title, Der Weltkrieg. The corresponding French official history has the title: Les Armées Françaises dans la Grande Guerre, published by the French general staff. There are approximately one hundred volumes issued to date. The official work commemorating Great Britain's military efforts bears the title: The History of the Great War Based on Official Documents. The portion of the work completed to date has been published in some fifty volumes. Supplementing these official records are the regimental histories of the various military units of the belligerent powers. The library has over 1000 volumes of such records of France, Germany, Great Britain, and the United States.

But the personal element has not been neglected. It is represented in the memoirs of such leaders as Ludendorff, Hindenburg, and Tirpitz for the Central Powers; and in the works of Foch, Joffre, Haig, Kitchener, and Pershing for the Allied Powers. The personal side of the war is also shown in the accounts of the infantryman, the cavalryman, the sailor, the aviator, and in the war narratives of the doctor, the nurse, and the ambulance driver. Secondary accounts of military campaigns and battles are numerous also. The catalog of the Hoover Library contains approximately 700 entries under the subject heading: European War-Campaigns with its various subdivisions.

These studies and accounts of military operations are supplemented by maps and photographs. The maps are representative of all countries and are both official and unofficial in character. For example, a study of American military operations can be facilitated by the use of United States general staff maps for the various regions of the western front in which American activitiescentered. These maps, consisting of over one thousand sheets, are of various scales. For British military operations there is a wide variety of maps issued by the geographical section of the British general staff. Also of special in- 
terest are charts prepared by the British admiralty showing the position of German mine fields in the Baltic regions, the positions of American and British mines ir the North Sea area, and the mine clearance areas in these regions after the war.

The activities of military forces in various regions are vividly portrayed in the proclamations issued in occupied territories. The events of the German occupation of Belgium are recorded for future scholars in the Grace Davis Booth Collection of original proclamations issued by the German authorities during the years I9I4-I8. This collection, organized in 77 specially made boxes, contains $2 \mathrm{I} 32$ items. Another similar collection contains about 2300 proclamations issued by civil and military authorities in the city of Berlin during the period of the war.

The military journal plays an important part in the historical record and it has likewise been preserved. The Hoover Library possesses over 200 files in the German language, $3 \mathrm{I}$ in English, 93 in French, as well as smaller groups in Russian, Italian, Polish, and other languages. These journals range from daily papers published in the field to hospital and prison camp papers. They were often issued as mimeographed sheets, and at times were even printed on wallpaper.

But a history of the war cannot be limited to an account of military operations. The political and economic aspects are of equal importance. In these fields the official documents play a prominent role. The Hoover Library collection of official documents may be divided into two general classes: (I) national, state, and municipal documents; and (2) documents of national and international organizations having government connections.

The national and state documents in- clude the legislative debates and official journals for all countries, belligerent and neutral. The publications of the various foreign offices contribute to a study of diplomatic negotiations, while the records of the ministries of agriculture, commerce, labor, and industry all make their contribution to the study of wartime economy. The records of international organizations include reports and minutes of various inter-Allied bodies of the war period, such as the Allied Blockade Committee, the Allied Maritime Transport Council, and the Inter-Allied Munitions Council. Outstanding in this field are the records of the Paris Peace Conference, a most extensive collection of mimeographed and printed documents of this great international body created at the close of the war. The records include the minutes of the plenary sessions, the proceedings of the various committee meetings, and the bulletins of the various delegations.

\section{Has Publications of More Than 3500 Societies}

But the social, economic, and political phases of the war are also reflected in the records of various nongovernmental organizations. The reports of political parties, the pamphlets of special economic groups, the tracts of religious organizations, and the publications of societies with special political or racial interests all make contributions to the study of the war. In the records of the American Bankers' Association, the American Bible Society, the American Federation of Labor, the American Red Cross, the National Security League, the Jewish Welfare Board, the Catholic National Council, and the Y.M.C.A. the historian can trace the influence of the war upon American national life. The Hoover Library possesses 
publications of over 3500 societies in various countries for the war and postwar periods.

The newspaper is also an invaluable tool in a study of the war. For some countries, the newspaper holdings include all important groups of opinions and regions. For other countries there are one or two files only, but in such cases an effort has been made to secure one paper in sympathy with the government and one in opposition.

The active role of the press in war time is probably nowhere shown to better advantage than in a study of the newspaper and periodical press of Belgium during the period of German occupation, I9I 4I8. From the very beginning of this occupation, the importance of the press was acknowledged by the German authorities; evidence of this is shown by their extensive efforts to supervise all papers and journals in existence, and to establish new publications in order to control thought and public opinion. The Hoover Library possesses war-time files of 50 Belgian newspapers; they were issued in both the occupied and unoccupied territories, and in various Allied countries in which Belgians had taken refuge.

\section{Clandestine Publications}

The curtailment of the freedom of the press by the German authorities naturally resulted in the appearance of a vast amount of clandestine material of all kinds: books, pamphlets, cartoons, post cards, and periodicals which appeared wherever and whenever possible. The publication of these periodicals began early in August I9I4. By the summer of I9I5, twenty-five such journals had made their appearance. After July I9I5 new titles appeared less frequently, although they continued to appear until the armistice.

The clandestine Belgian serial is represented by a collection of about 55 titles, numbering over $\mathrm{I} 400$ issues. These serials varied in size and appeared both in mimeographed and printed form. In a few instances these secret publications appeared throughout the period of the war. This was true of the now famous Libre Belgique, which began in February I9I 5 and made its last appearance on the day after the armistice, November I2, I9I8. The Libre Belgique was primarily an organ of opinion and confined itself briefly to harassing the German authorities by satire and calumny. In jovial mood, its sponsors termed it "a bulletin of patriotic propaganda, regularly irregular." The library possesses a complete file of the original edition of I 7 I numbers. A check of the Union List of Serials discloses that, with the exception of the Libre Belgique, practically none of the clandestine titles are available in other libraries. It appears, therefore, that the Hoover Library collection is unique in America and probably unique in the world.

But any complete account of the war must give due consideration to the forces which controlled and affected the reaction of the individual toward the war. The successful prosecution of the war in every country necessitated the mobilization of the civilian mind. The efforts of governmental authorities to effect this mobilization resulted in the development of a phenomenon almost unknown until the beginning of the World War, namely, the extensive use of propaganda.

As used during the war, propaganda had three main objectives: (I) to arouse the domestic population in support of the war; (2) to win the support of neutral nations; (3) to destroy the morale of the 
enemy. Its methods in these three fields are exemplified by special materials in the Hoover Library.

The methods of appeal to the domestic population for support of the war varied; much was accomplished by the newspaper, the periodical, and the pamphlet. But perhaps the most effective tool in preparing the ground for the general support of the war was the pictorial poster. Its important role is strikingly shown in the Hoover Library collections. Posters, placards, and proclamations from all the belligerent nations have been collected and organized. It is noteworthy that the posters of each country were based on identical psychological appeals. The call to "save food" echoed in Germany as well as in France and America.

The attempts of belligerents to win support of neutrals is shown by hundreds of pamphlets and books in the library. This propaganda material was distributed by both the Allied and Central powers in an attempt to gain the sympathy and support of civilians in neutral countries. One collection in the library presents the materials distributed in South America by the Allied and Central powers to gain sympathy for their respective causes. Another example is furnished by a collection of German propaganda distributed in the United States prior to our entry into the World War in 1917. Still a third is a collection of British propaganda distributed in the United States during the same period.

The third main objective of propaganda, that of destroying the morale of the enemy, can be studied by the use of a large collection of broadsides which were dropped over the German lines from Allied airplanes. The purpose of these broadsides was to arouse in the mind of the enemy a sense of unrest and despair.
A few words concerning the policy of the Hoover Library may be of interest. The library is primarily a reference library. Although books appearing in the current book trade are allowed to circulate, all government documents, newspapers, periodicals, and materials in special collections are for reference use only. The facilities of the library are primarily for the faculty and graduate students of Stanford University. The library is open, however, to the faculty and graduate students of other universities and to other qualified investigators upon presentation of credentials.

Plans are now progressing for the erection of a new building to house the Hoover Library on War, Revolution, and Peace. Through the generosity of various private donors and foundations, a sum of $\$ 600,000$ has been made available for this purpose. The new building will be constructed in tower form, and will rise 280 feet above the ground level. The architecture has been designed to harmonize with the existing buildings of Stanford University.

The Hoover Library may be called an international archive, comparable in scope to the archives of a great state. Its widespread use by local, national, and even international scholars testifies to its importance in the field of historical research. The library is continually progressing along the lines laid down by its originators, and is already realizing the aims of its founder in presenting an interpretation of the past and present for the benefit and guidance of the future. With the increased facilities of the new building, which will make all the library's resources available to the scholar, the Hoover Library is destined to become a world center for research on the World War and the subsequent world order. 